\title{
Stan drobnej leżaniny w lasach gospodarczych i rezerwatach Puszczy Niepołomickiej
}

\author{
PaweŁ Zduńczyk, Łukasz Piechnik, Grażyna Szarek-Łukaszewska, \\ Jan HoleKsa i PaweE KapUSTA
}

Zduńczyk, P., Piechnik, Ł., Szarek-Łukaszewska, G., Holeksa, J. And Kapusta, P. 2020. Stock of downed fine woody debris in managed forests and nature reserves of the Niepołomice Forest. Fragmenta Floristica et Geobotanica Polonica 27(1): 141-153. Kraków. e-ISSN 2449-8890, ISSN 1640-629X.

\begin{abstract}
This study was aimed at determining the amount of downed fine woody debris (FWD) in managed stands and nature reserves of the Niepołomice Forest, comparing it with the amount of downed coarse woody debris (CWD), and identifying the factors affecting FWD. The measurements were carried out in 99 study plots established in mixed (pine-dominated) and deciduous forests. The volume of FWD in managed stands ranged from 0.9 to $16.9 \mathrm{~m}^{3} \mathrm{ha}^{-1}$. The median value for FWD $\left(5.0 \mathrm{~m}^{3} \mathrm{ha}^{-1}\right)$ was twice that for CWD volume. The share of FWD in the total volume of downed woody material ranged from $7.7 \%$ to $100 \%$ (median $64.4 \%$ ). In the reserves, CWD dominated; its volume was between 13.2 and $175.4 \mathrm{~m}^{3} \mathrm{ha}^{-1}$ and its share was $\sim 80 \%$. The type of forest significantly affected FWD; its volume was higher in deciduous forests. Among other stand parameters, the number of tree species correlated most with FWD volume $\left(r_{S}=0.41, p<0.0001\right)$. The study showed that FWD constitutes a significant part of the deadwood pool in managed stands and, as such, can be important in shaping the diversity of deadwood-dependent organisms.
\end{abstract}

KEY WORDS: coarse woody debris, downed woody material, fine woody debris, managed forests, nature reserves, Niepołomice Forest

P. Zduńczyk (autor korespondencyjny), L. Piechnik, G. Szarek-Lukaszewska, P. Kapusta, Instytut Botaniki im. W. Szafera Polskiej Akademii Nauk, ul. Lubicz 46, 31-512 Kraków, Polska; e-mail: p.zdunczyk@botany.pl; l.piechnik@botany.pl; g.szarek@botany.pl; p.kapusta@botany.pl

J. Holeksa, Zakład Ekologii Roślin i Ochrony Środowiska, Wydziat Biologii, Uniwersytet im. Adama Mickiewicza w Poznaniu, ul. Uniwersytetu Poznańskiego 6, 61-614 Poznań, Polska; e-mail: jan.holeksa@amu.edu.pl

\section{WSTĘP}

Martwe drewno, czyli obumarłe drzewa lub ich części, jest niezbędnym składnikiem dobrze funkcjonujących ekosystemów leśnych. Pełni ono wiele funkcji - uczestniczy w obiegu materii, zwiększa możliwości retencji wody, kształtuje warunki mikrosiedliskowe (HARMON i in. 1989; LAiHo \& Prescott 2004; MerganiČOvá i in. 2012; LASOTA i in. 2018), ale przede wszystkim stanowi pożywienie lub środowisko życia dla dużej grupy organizmów, wpływając korzystnie na bioróżnorodność biocenozy leśnej (GuTOWSKI i in. 2004; 
STOKLAND i in. 2012; BALDRIAN 2017). Liczba publikacji dotyczących martwego drewna jest znaczna i z roku na rok szybko się powiększa. Są to jednak publikacje koncentrujące się niemal wyłącznie na drewnie wielkowymiarowym - całych obumarłych drzewach lub ich dużych fragmentach (ang. coarse woody debris). Znacznie mniej uwagi w badaniach ekologicznych poświęca się drobnemu martwemu drewnu (ang. fine woody debris), na które składają się gałązki, gałęzie i inne zdrewniałe szczątki drzew i krzewów, nieprzekraczające grubości $10 \mathrm{~cm}$. Zakres tematyczny prac, w których pojawia się ta frakcja drewna, obejmuje najczęściej ocenę zagrożenia pożarowego (LuTES i in. 2009; Polo i in. 2013; ZhaO i in. 2014; StALling i in. 2017), modelowanie bilansu węgla (Woodall i in. 2008, 2013; VAVRova i in. 2009; DomKe i in. 2016), czy szacowanie kosztów prac hodowlanych i gospodarowanie biomasą (drobne drewno wchodzi w skład resztek pozrębowych i często opisywane jest w tym właśnie kontekście) (SADOWSKI i in. 2012; LõHMUS i in. 2013; GoŁos \& KAliszewski 2015; Thiffault $\mathrm{i}$ in. 2015). Tymczasem drobne drewno, tak jak drewno wielkowymiarowe, może pełnić funkcję źródła pożywienia i mikrosiedliska dla wielu gatunków grzybów, bezkręgowców i innych organizmów, przyczyniając się do podtrzymywania saproksylicznej sieci pokarmowej. Wskazują na to wyniki niektórych, wciąż nielicznych badań (KRUYS \& JONSSON 1999; NORDÉN i in. 2004b; KÜFFER i in. 2008; CASTRO \& WiSE 2009; JuUtilainen i in. 2011; Riffell i in. 2011; SEIBOld i in. 2016; MAŇÁK \& JonSELL 2017). Drobne drewno wydaje się mieć szczególnie duże znaczenie w lasach gospodarczych - jest to jedyny element, który może, przynajmniej częściowo, rekompensować niedostatek wielkowymiarowego martwego drewna.

Niniejsze badania miały na celu: 1) opisanie stanu drobnej leżaniny, tj. drobnego martwego drewna leżącego w dnie lasu, w dojrzałych drzewostanach gospodarczych i rezerwatach Puszczy Niepołomickiej, 2) porównanie go ze stanem wielkowymiarowego martwego drewna oraz 3) określenie relacji pomiędzy ilością drobnego drewna a wybranymi parametrami drzewostanów gospodarczych.

\section{MATERIAŁY I METODY}

Badania były prowadzone w Puszczy Niepołomickiej - dużym, dobrze zachowanym kompleksie lasów nizinnych, położonym w okolicach Krakowa. Kompleks jest siedliskowo wyraźnie zróżnicowany. W jego północnych częściach dominują drzewostany liściaste tworzone przede wszystkim przez Carpinus betulus, Quercus robur oraz Tilia cordata, natomiast na południu panują drzewostany mieszane, które tworzy głównie Pinus sylvestris oraz $Q$. robur i $Q$. petraea. W niektórych rejonach południowej części kompleksu występują niewielkie drzewostany bukowe oraz plantacje modrzewiowe, a w obniżeniach terenu całego kompleksu drzewostany olchowe i jesionowe.

Niniejsza praca jest częścią większego projektu dotyczącego między innymi relacji między dostępnością martwego drewna w lasach gospodarczych a występowaniem gatunków roślin i zwierząt. Liczba i rozmieszczenie powierzchni badawczych zostały dostosowane do celów projektu. Wyznaczono ich łącznie 100, z czego 94 ulokowano w drzewostanach gospodarczych (w tym $2 \mathrm{w}$ tzw. drzewostanach referencyjnych), a 6 w czterech rezerwatach przyrody (Ryc. 1). Ostatecznie do obliczeń (statystyk opisowych) użyto danych z 99 powierzchni - wykluczono jedną powierzchnię (założoną w rezerwacie), na której przed wykonaniem pomiarów drobnej leżaniny powstał wiatrował (uzyskane dla niej wartości uznano za odstające). Spośród drzewostanów gospodarczych wytypowano drzewostany dojrzałe (tj. takie, których wiek, uśredniony dla powierzchni, przekraczał 60 lat), o jednorodnej strukturze, reprezentujące dominujące typy 


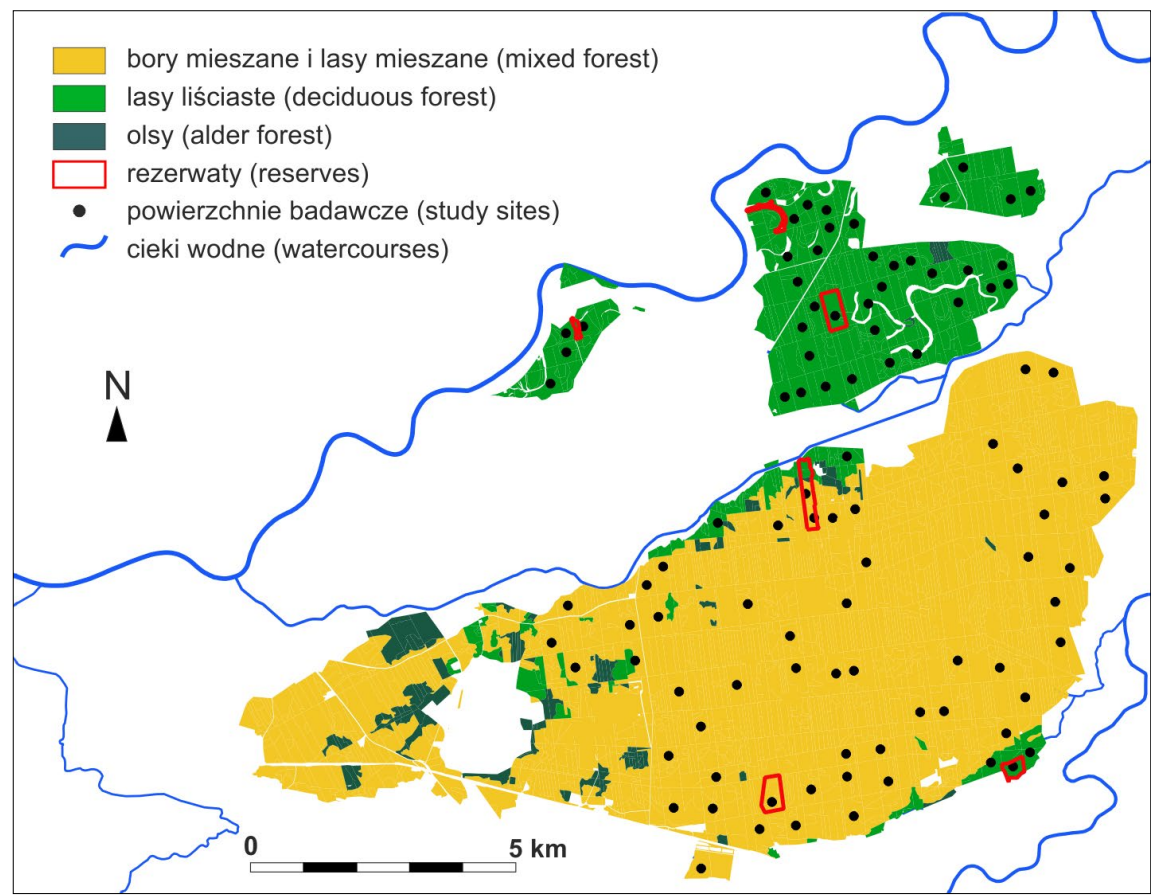

Ryc. 1. Rozmieszczenie powierzchni badawczych na obszarze Puszczy Niepołomickiej na tle dominujących typów drzewostanów

Fig. 1. Location of study plots in the Niepołomice Forest in relation to the dominant types of tree stands

siedliskowe lasu: 1) bory mieszane oraz lasy mieszane $\mathrm{z}$ dużym udziałem sosny, $\mathrm{w}$ wariantach świeżym i wilgotnym, określane skrótem „BLM” ( $\mathrm{N}=49) ; 2)$ lasy, w wariantach świeżym i wilgotnym, określane skrótem „L” $(\mathrm{N}=50)$. W badaniach nie uwzględniono zachodniej części Puszczy Niepołomickiej, jako znacznie przekształconej w wyniku działalności człowieka.

Powierzchnie badawcze miały kształt prostokąta o wymiarach $20 \times 100 \mathrm{~m}$. W jego obrębie wykonano pomiary drzewostanu oraz wielkowymiarowej leżaniny (WL) według metodyki opisanej przez KAPUSTE $\mathrm{i}$ in. (2020). Miąższość drobnej leżaniny (DL) określono metodą linii siecznej (ang. line intercept method); wewnątrz każdej powierzchni wytyczono transekt o długości $100 \mathrm{~m}$, a następnie zmierzono średnice wszystkich gałęzi, gałązek i innych fragmentów DL (tj. nie przekraczających średnicy $10 \mathrm{~cm}$ ) przecinanych przez ten transekt. Miąższość DL wyliczono ze wzoru proponowanego przez VAN WAGNERA (1968):

$$
V=\sum d^{2} \pi^{2}(8 L)^{-1},
$$

gdzie $d$ jest średnicą pojedynczego fragmentu DL leżącego na transekcie (tj. w miejscu przecięcia z linią sieczną), a $L$ długością linii siecznej.

Analizę korelacji i testy statystyczne przeprowadzono dla danych zebranych z 94 powierzchni gospodarczych. Istotność różnic w miąższości DL oraz miąższości WL pomiędzy dwoma typami drzewostanów (BML i L) określono za pomocą testu Manna-Whitneya. Testu Wilcoxona dla par wiązanych użyto do porównania miąższości DL z miąższością WL występujących w obrębie tej samej powierzchni. Zależność pomiędzy DL i wybranymi parametrami drzewostanu (zagęszczeniem drzew, pierśnicowym polem przekroju drzew, miąższością drzew, liczbą gatunków drzew, liczbą pniaków, polem przekroju pniaków oraz wiekiem drzewostanu) zbadano przy użyciu korelacji rang Spearmana. Parametry drzewostanu zostały określone w sposób opisany przez KAPUSTĘ i in. (2020). Analizy statystyczne wykonano w programie PAST 3 (HAMMER i in. 2001). 


\section{WYNIKI}

Miąższość leżącego martwego drewna na terenie Puszczy Niepołomickiej była silnie zróżnicowana. W drzewostanach gospodarczych miąższość DL mieściła się w przedziale od 0,9 do $16,9 \mathrm{~m}^{3} \mathrm{ha}^{-1}$ (mediana: 5,0 $\mathrm{m}^{3} \mathrm{ha}^{-1}$ ), natomiast miąższość WL oscylowała w zakresie 0-52,1 $\mathrm{m}^{3} \mathrm{ha}^{-1}$ (mediana: 2,5 $\mathrm{m}^{3} \mathrm{ha}^{-1}$ ). Biorąc pod uwagę wartości mediany, miąższość DL na powierzchniach badawczych była przeciętnie dwa razy większa niż miąższość WL; różnica była istotna statystycznie $(W=2907 ; p=0,011$; Ryc. 2a). Udział DL w miąższości całej leżaniny wahał się w szerokich granicach, od 7,7 do $100 \%$; przeciętna wartość (mediana) wynosiła 64,4\% (Ryc. 3).

W rezerwatach miąższość leżaniny, odpowiednio DL i WL, przedstawiała się następująco: 11,3 i 175,3 $\mathrm{m}^{3} \mathrm{ha}^{-1}$ w rezerwacie „Lipówka”, 4,7 i 24,5 $\mathrm{m}^{3} \mathrm{ha}^{-1} \mathrm{w}$ rezerwacie „Gibiel” (wartości uśrednione $\mathrm{z}$ dwóch powierzchni), 7,0 i 14,5 $\mathrm{m}^{3} \mathrm{ha}^{-1} \mathrm{w}$ rezerwacie „Dębina” oraz 7,4 i 15,3 $\mathrm{m}^{3} \mathrm{ha}^{-1}$ w rezerwacie „Długosz Królewski”. W przeciwieństwie do drzewostanów gospodarczych miąższość WL przewyższała miąższość DL; udział DL w całości leżaniny wynosił tu średnio tylko 19,1\% (Ryc. 3).

a)

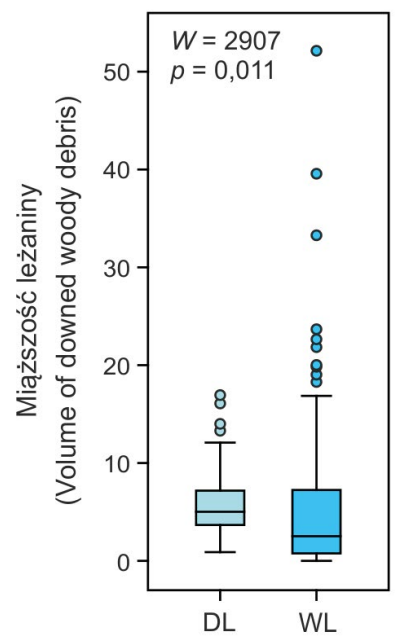

Typ leżaniny

(Downed dead wood type) b)

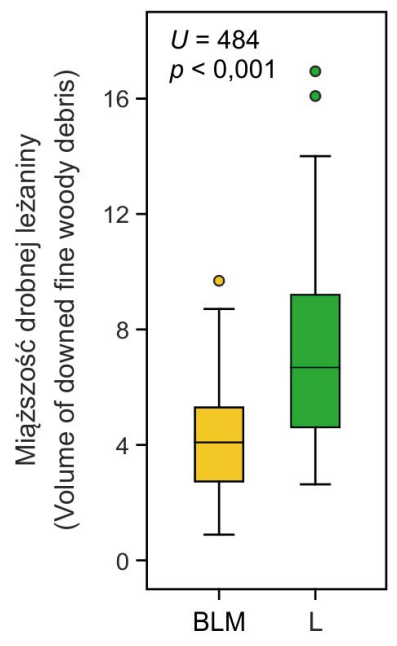

Typ lasu

(Type of forest)
C)

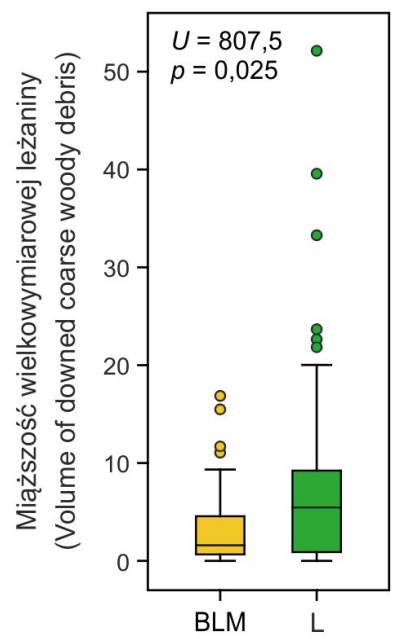

Typ lasu (Type of forest)

Ryc. 2. Miąższość leżaniny $\left(\mathrm{m}^{3} \mathrm{ha}^{-1}\right)$ w drzewostanach gospodarczych Puszczy Niepołomickiej: a) drobna (DL) i wielkowymiarowa (WL) leżanina; b) DL z podziałem na typy lasów (BLM - bory mieszane i lasy mieszane, L - lasy); c) WL z podziałem na typy lasów. Wykresy pudełkowe przedstawiają medianę, pierwszy i trzeci kwartyl, wartość minimalną i maksymalną oraz wartości odstające. Nad wykresami podano wartość statystyki testowej oraz istotność statystyczną dla porównywanych grup

Fig. 2. The volume of downed dead wood $\left(\mathrm{m}^{3} \mathrm{ha}^{-1}\right)$ in managed stands of the Niepołomice Forest: a) fine (DL) and coarse (WL) woody debris; b) DL according to forest type (BLM - pine-dominated mixed forest, L - deciduous forest); c) WL according to forest type. Box plots represent the median, first and third quartiles, the minimum and maximum values, and outliers. The test statistic values and statistical significance for the compared groups are given above the box plots 


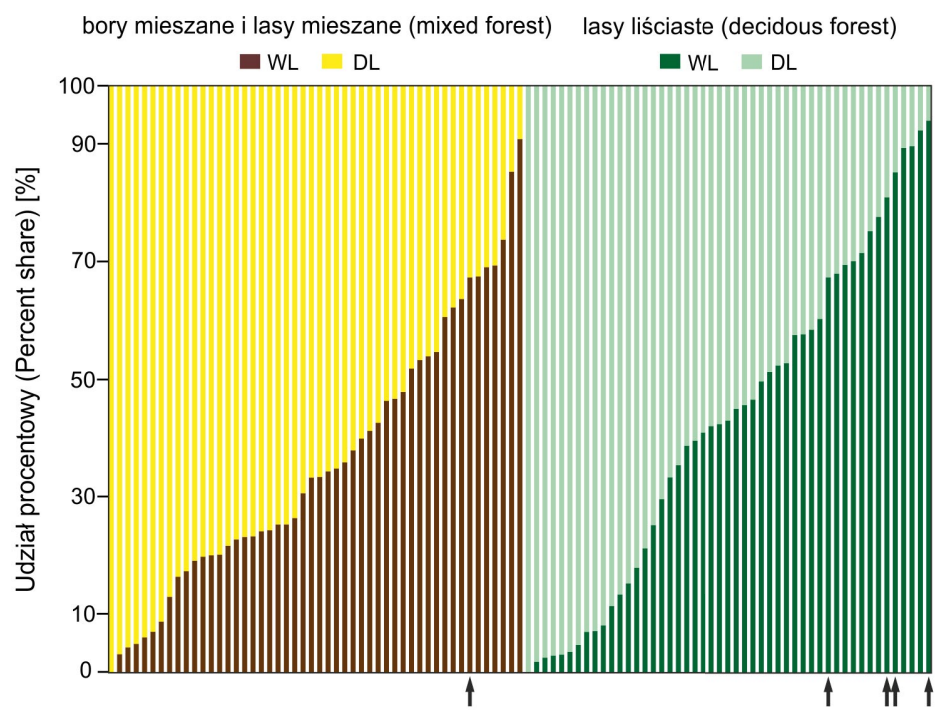

Ryc. 3. Udziały procentowe drobnej (DL) i wielkowymiarowej (WL) leżaniny na poszczególnych powierzchniach badawczych. Powierzchnie zostały rozdzielone na bory mieszane i lasy mieszane (BLM) oraz lasy (L) i uszeregowane według rosnących wartości WL. Strzałki wskazują rezerwaty przyrody

Fig. 3. Percent shares of downed fine (DL) and coarse (WL) woody debris for individual study plots, shown for two types of forests, pine-dominated mixed forests (BLM) and deciduous forests (L), separately and ranked according to increasing WL values. Arrows indicate nature reserves

Liczebnościowo najwięcej DL (54\% - łącznie dla drzewostanów gospodarczych i rezerwatów) przynależało do pierwszej klasy grubości (poniżej $10 \mathrm{~mm}$ ). W kolejnych klasach liczba fragmentów DL była znacznie niższa; prawie 98\% DL nie przekraczało grubości $50 \mathrm{~mm}$ (Ryc. 4).

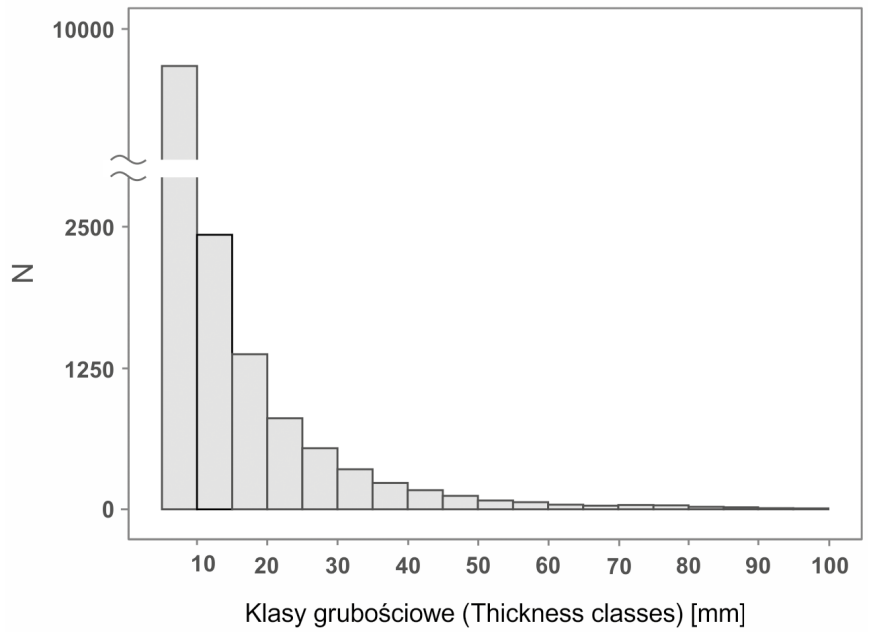

Ryc. 4. Liczebność (N) drobnej leżaniny w poszczególnych klasach grubości

Fig. 4. Number $(\mathrm{N})$ of pieces of downed fine woody debris in particular thickness classes 
Tabela 1. Parametry drzewostanu i ich związek (reprezentowany przez współczynnik korelacji Spearmana $r_{S}$ i poziom istotności statystycznej p) z miąższością drobnej leżaniny dla 94 powierzchni badawczych założonych w drzewostanach gospodarczych. Pogrubioną czcionką zaznaczono wartości $p<0,05$

Table 1. Tree stand parameters and their relationship (represented by Spearman's $r_{S}$ coefficients and statistical significance levels $p$ ) with the volume of downed fine woody debris for 94 study plots established in managed stands. $p$-values $<0.05$ are in bold

\begin{tabular}{|c|c|c|c|c|}
\hline $\begin{array}{l}\text { Parametry drzewostanu } \\
\text { Tree stand parameters }\end{array}$ & $\begin{array}{l}\text { Mediana } \\
\text { Median }\end{array}$ & $\begin{array}{l}\text { Zakres } \\
\text { Range }\end{array}$ & $r_{S}$ & $p$ \\
\hline $\begin{array}{l}\text { Zagęszczenie drzew (osobników ha-1) } \\
\text { Tree density (individuals ha-1) }\end{array}$ & 330 & $105-590$ & $-0,13$ & 0,2129 \\
\hline $\begin{array}{l}\text { Pierśnicowe pole przekroju drzew }\left(\mathrm{m}^{2} \mathrm{ha}^{-1}\right) \\
\text { Basal area of trees }\left(\mathrm{m}^{2} \mathrm{ha}^{-1}\right)\end{array}$ & 32,7 & $6,8-49,1$ & $-0,03$ & 0,7760 \\
\hline $\begin{array}{l}\text { Miąższość drzew }\left(\mathrm{m}^{3} \mathrm{ha}^{-1}\right) \\
\text { Tree stand volume }\left(\mathrm{m}^{3} \mathrm{ha}^{-1}\right)\end{array}$ & 378 & $69-710$ & 0,10 & 0,3468 \\
\hline $\begin{array}{l}\text { Bogactwo gatunkowe drzew (liczba gatunków na powierzchnię) } \\
\text { Tree species richness (number of species per study plot) }\end{array}$ & 4 & $2-8$ & 0,41 & $<0,0001$ \\
\hline $\begin{array}{l}\text { Liczba pniaków (sztuk ha-1) } \\
\text { Number of stumps (pieces ha }{ }^{-1} \text { ) }\end{array}$ & 65 & $10-315$ & $-0,10$ & 0,3202 \\
\hline $\begin{array}{l}\text { Pole przekroju pniaków }\left(\mathrm{m}^{2} \mathrm{ha}^{-1}\right) \\
\text { Basal area of stumps }\left(\mathrm{m}^{2} \mathrm{ha}^{-1}\right)\end{array}$ & 7,3 & $0,5-24,7$ & 0,27 & $\mathbf{0 , 0 0 9 7}$ \\
\hline $\begin{array}{l}\text { Wiek drzewostanu (lat) } \\
\text { Tree stand age (yr) }\end{array}$ & 87 & $42-172$ & 0,18 & 0,0881 \\
\hline
\end{tabular}

Typ lasu miał istotny wpływ na miąższość obu typów leżaniny. Biorąc pod uwagę wartości mediany, w drzewostanach liściastych (L) było przeciętnie ponad półtora razy więcej DL $(U=484 ; p<0,001$; Ryc. 2 b) i prawie 3,5 razy więcej $\mathrm{WL}(U=807,5 ; p=0,025$; Ryc. 2c) niż w drzewostanach mieszanych (BML). Związek miąższości DL z innymi parametrami drzewostanu był słaby lub nieistotny (Tab. 1); wśród istotnych statystycznie korelacji najsilniejsza była pozytywna korelacja $\mathrm{z}$ bogactwem gatunkowym drzew $\left(r_{S}=0,41\right.$; $p<0,0001)$.

\section{DYSKUSJA}

W ciągu ostatnich kilku dekad pojawiło się wiele publikacji, których głównym lub pobocznym tematem była charakterystyka zasobów martwego drewna w lasach. Publikacje te dostarczają cennych danych na temat zróżnicowania ilości i jakości martwego drewna, np. pomiędzy regionami geograficznymi, typami siedlisk, czy sposobami użytkowania ekosystemu. Dane te obejmuja głównie drewno o dużych rozmiarach (TER-MikaELian i in. 2008; MoRRISSEY i in. 2014; DAVIS i in. 2015; JONSSON i in. 2016). Prace zawierające informacje o drewnie drobnowymiarowym są stosunkowo nieliczne. Te, których wyniki pochodzą z badań prowadzonych w lasach strefy umiarkowanej (MCCARTHY \& BAILEY 1994; NordÉn i in. 2004a; LÕHMUS \& Kraut 2010; LitTLEFIELd \& KeEton 2012; WoOdall $i$ in. 2013; BeHJou i in. 2014; SÖDERBERG i in. 2014; TOMUSIAK i in. 2014; Herrero i in. 2016) pokazują, że przeciętna ilość drobnego drewna może się wahać w szerokich granicach - od 0,9 do $30 \mathrm{~m}^{3} \mathrm{ha}^{-1}$ (lub, w jednostkach wagowych, od 1 do $28 \mathrm{Mg} \mathrm{ha}^{-1}$ ). Udział tej 
frakcji w całości martwego drewna też jest silnie zróżnicowany. Oscyluje w przedziale między kilka a kilkadziesiąt procent, stanowiąc w wielu przypadkach ponad 1/3 całkowitej puli martwego drewna, przy czym niższe udziały DL notowane są na ogół w lasach wyłączonych z użytkowania, np. rezerwatach lub lasach użytkowanych mało intensywnie (LõHMUS \& Kraut 2010; Müller \& Bütler 2010; Banaś i in. 2014; BeHJou i in. 2014; BujocZeK i in. 2018). Dane zebrane w Puszczy Niepołomickiej nie odbiegają od danych z literatury; jeśli chodzi o miąższość, lokują się bliżej dolnej granicy podawanego wyżej zakresu, a jeśli chodzi o udział - w jego środkowej części.

W dojrzałych drzewostanach gospodarczych Puszczy Niepołomickiej (w wieku >60 lat) przeciętna miąższość drobnej leżaniny (DL) na powierzchniach badawczych była istotnie większa od przeciętnej miąższości wielkowymiarowej leżaniny (WL). W efekcie DL przeważała nad WL pod względem udziału w całości leżaniny (stanowiąc ponad 60\%). Stan ten jest w dużej mierze efektem gospodarki ukierunkowanej na produkcję surowca drzewnego, która nie sprzyja akumulacji martwego drewna w postaci całych obumarłych drzew lub ich dużych fragmentów. Straty WL powstałe w wyniku pozyskiwania drewna na sprzedaż oraz prac pielęgnacyjnych (np. trzebieży) powodują, że DL staje się w wielu miejscach dominującą, a czasem nawet jedyną frakcją leżaniny. O tym jak duża jest ingerencja gospodarki leśnej w stan WL świadczy - na zasadzie kontrastu - udział DL rezerwatach, który wyniósł przeciętnie poniżej 20\%. W drzewostanach wyłączonych z użytkowania akumulacja WL jest ograniczana tylko przez czynniki naturalne, w związku z czym ta frakcja drewna może objętościowo znacznie przewyższać DL. Miąższość DL wydaje się być mniej uzależniona od zabiegów gospodarczych niż miąższość WL. DL była obecna na każdej z badanych powierzchni i charakteryzowała się mniejszą zmiennością (współczynnik zmienności dla DL wynosił 56\%, a dla WL - $146 \%$ ). Małe zainteresowanie pozyskiwaniem DL powoduje, że na jej ilość i zmienność większy wpływ mogą mieć czynniki naturalne (np. obłamywanie lub obumieranie gałęzi na skutek uszkodzeń powodowanych przez wiatr) niż działalność człowieka. Wpływ człowieka na stan DL, chociaż jest niewielki, nie jest zerowy. Drobne gałęzie oddzielone od pni w trakcie cięć pielęgnacyjnych nie zawsze są pozostawiane w lesie; bywają one uprzątane przez pracowników leśnych i wykorzystywane do produkcji zrębków wykorzystywanych w ogrodnictwie. W Puszczy Niepołomickiej praktykowane jest też udzielanie licencji na samodzielne pozyskiwanie drobnego drewna do celów opałowych (tzw. „samowyrób”).

Na miąższość DL (ale także i WL) znacząco wpływał typ drzewostanu; w drzewostanach liściastych (L) notowano więcej leżaniny niż w drzewostanach mieszanych (BML). Wynik ten może być związany z odmiennymi właściwościami drewna gatunków budujących badane typy drzewostanów, ale także z odmienną historią i sposobem użytkowania dwóch części kompleksu leśnego. Część południowa Puszczy Niepołomickiej (z drzewostanami mieszanymi) zawsze była bardziej dostępna, a tym samym intensywniej użytkowana niż podmokła część północna (z drzewostanami liściastymi). Co więcej, warunki siedliskowe tej pierwszej zostały na przestrzeni lat znacząco zmienione (obniżono poziom wód gruntowych, budując rozległą sieć rowów drenarskich), a panujące tam drzewostany mieszane w znaczniej mierze przebudowane w kierunku jednogatunkowych monokultur (głównie sosnowych). Obecnie trwa proces odtwarzania składu gatunkowego zgodnego z siedliskiem 
i drzewostany jednogatunkowe części południowej są przebudowywane w kierunku drzewostanów wielogatunkowych. Bardzo możliwe, że wynikająca z tego większa intensywność i częstotliwość prac hodowlanych przyczynia się do eliminacji potencjalnych źródeł drobnej leżaniny (np. starych, uszkodzonych czy zamierających drzew).

Spośród wybranych parametrów drzewostanu z miąższością DL najsilniej korelowała (pozytywnie) liczba gatunków drzew. Związek ten nie był zależny od typu lasu. Wynik ten można różnie tłumaczyć. W drzewostanach charakteryzujących się dużym bogactwem gatunkowym istnieje większe prawdopodobieństwo wystąpienia gatunków, które naturalnie generują dużo drobnego posuszu lub są bardziej podatne na uszkodzenia (np. będące efektem „biczowania” innych drzew) (HAJEK i in. 2015). Do takich gatunków należy np. grab (FALIŃSKI \& PAWLACZYK 1993), będący ważnym składnikiem drzewostanów Puszczy Niepołomickiej. Zaobserwowany związek może być też efektem działalności człowieka. W drzewostanach typowo produkcyjnych, które często maja postać jednogatunkowych upraw, zabiegi pielęgnacyjne są ukierunkowane na uzyskanie surowca o jak najlepszej jakości, w związku z czym obejmują one usuwanie osobników gorzej wykształconych, uszkodzonych i zamierających, będących potencjalnym źródłem DL. W drzewostanach wielogatunkowych tego typu zabiegi mogą być mniej intensywne.

Znikoma ilość i niewielkie zróżnicowanie rodzajów martwego drewna w wielu lasach gospodarczych stanowi dużą przeszkodę w skutecznej ochronie gatunków, nie tylko tych ściśle związanych z martwym drewnem (STOKLAND $\mathrm{i}$ in. 2012; JoHANsSOn $\mathrm{i}$ in. 2016; NORDÉN i in. 2018; JAWORSKI i in. 2019). Najbardziej dotkliwy jest niedostatek drewna wielkowymiarowego, tj. całych obumarłych drzew lub ich dużych fragmentów, np. kłód, złomów, wykrotów itp. (GUTOWSKI i in. 2004; MÜlLER \& BÜTLER 2010; STOKLAND i in. 2012; VITKOVA i in. 2018; KAPUSTA i in. 2020). Drobne martwe drewno nie jest w stanie zastąpić drewna wielkowymiarowego w jego roli ekologicznej - jako pożywienia i mikrosiedliska wielu organizmów saproksylicznych. Może jednak pełnić istotną rolę tam, gdzie drewna wielkowymiarowego nie ma w ogóle lub jest go bardzo niewiele, np. w większości drzewostanów Puszczy Niepołomickiej. Pozostawianie drobnego drewna (drobnej leżaniny) w drzewostanach i na zrębach sprzyja występowaniu organizmów korzystających z tego szybko rozkładającego się materiału, czyli przeważnie niewielkich grzybów (KRUYS \& JONSSON 1999; NoRdÉn i in. 2004b; KüFFER \& SENN-IRLET 2005; JuUtILAINEN i in. 2011, 2014). Z drobnym drewnem związane są niektóre saproksyliczne workowce i należące do podstawczaków grzyby kortycjoidalne (KÜFFER i in. 2008; BäSSLER i in. 2010; ABREGO \& SALCEDO 2011, 2013; KunTtu i in. 2018; MarTíneZ i in. 2019). Od obecności drobnego drewna może zależeć także obfitość i różnorodność innych grup organizmów, np. porostów i mszaków (KRUYS \& JONSSON 1999; HÄMÄLÄINEN i in. 2015), pająków (CASTRO \& WISE 2009) i chrząszczy (BRIN i in. 2011; MAŇÁK \& Jonsell 2017). Niektóre prace pokazują, że drobne drewno, które jest pozostawiane w lesie w formie zwartych stosów i stert, tworzy wartościowe schronienie dla małych kręgowców (MANNING \& EDGE 2008; DraCuP i in. 2015; ROMANO i in. 2018).

Podsumowując, drobne martwe drewno jest ważnym składnikiem ekosystemów leśnych. Rozkładające się gałęzie lub inne niewielkie fragmenty drewna są dla wielu organizmów istotnym źródłem materii i energii (PALVIAINEN i in. 2004; Klockow i in. 2013; PAILlET 
i in. 2013). Drobne drewno umożliwia egzystencję części mniej wyspecjalizowanych organizmów saproksylicznych, a dla innych organizmów kreuje odpowiednie warunki siedliskowe (Bouget $i$ in. 2012; Dracup i in. 2015; SEIBOLD i in. 2016; KIRCHENBAur i in. 2017; RANIUS $i$ in. 2018). W lasach gospodarczych drobna leżanina, oprócz pniaków, jest często jedyną liczącą się formą martwego drewna. W związku z tym zarządzanie jej zasobami, w kontekście zachowania dobrej kondycji biocenozy leśnej, powinno być częścią planów urządzeniowych.

Podziękowania. Badania były finansowane z środków Państwowego Gospodarstwa Leśnego Lasy Państwowe w ramach grantu pt. Kształtowanie się zasobów martwego drewna $w$ siedliskach przyrodniczych $w$ warunkach prowadzenia zrównoważonej gospodarki leśnej ( $\mathrm{Nr}$ OR.271.3.9.215) oraz środków statutowych Instytutu Botaniki im. W. Szafera Polskiej Akademii Nauk. Autorzy dziękują również Nadleśnictwu Niepołomice za umożliwienie prowadzenia badań na terenie Puszczy Niepołomickiej oraz wszystkim osobom, które brały udział w pracach terenowych.

\section{LITERATURA}

Abrego N. \& Salcedo I. 2011. How does fungal diversity change based on woody debris type? A case study in Northern Spain. - Ekologija 57: 109-119.

Abrego N. \& SALCEDo I. 2013. Variety of woody debris as the factor influencing wood-inhabiting fungal richness and assemblages: Is it a question of quantity or quality? - Forest Ecology and Management 291: $377-385$.

BALDRIAN P. 2017. Forest microbiome: Diversity, complexity and dynamics. - FEMS Microbiology Reviews 41(2): 109-130.

Banaś J., Bujoczek L., ZięBA S. \& Drozd M. 2014. The effects of different types of management, functions, and characteristics of stands in Polish forests on the amount of coarse woody debris. - European Journal of Forest Research 133: 1095-1107.

BÄSSler C., Müller J., DzIock F. K. \& BRANDl R. 2010. Effects of resource availability and climate on the diversity of wood-decaying fungi. - Journal of Ecology 98: 822-832.

Bouget C., LASSAuce A. \& Jonsell M. 2012. Effects of fuelwood harvesting on biodiversity - a review focused on the situation in Europe. - Canadian Journal of Forest Research 42(8): 1421-1432.

Behjou F., Mollabashi O. \& Amirahmadi N. 2014. Effects of management on the amount and characteristics of woody debris in mixed stands of Caspian forests. - BioResources 9(3): 4108-4116.

Brin A., Bouget C., Brustel H. \& Jactel H. 2011. Diameter of downed woody debris does matter for saproxylic beetle assemblages in temperate oak and pine forests. - Journal of Insect Conservation 15: 653-669.

Bujoczek L., SzewczyK J. \& BujoczeK M. 2018. Deadwood volume in strictly protected, natural, and primeval forests in Poland. - European Journal of Forest Research 137: 401-418.

CASTRO A. \& Wise D. H. 2009. Influence of fine woody debris on spider diversity and community structure in forest leaf litter. - Biodiversity Conservation 18: 3705-3731.

Davis J. G., Chapman J. I., Wu S.-Y. \& McEwan R. W. 2015. Spatiotemporal dynamics of coarse woody debris in an old-growth temperate deciduous forest. - Forest Science 61: 680-688.

Domke G., Perry C., Walters B., Woodall C., Russell M. \& Smith J. 2016. Estimating litter carbon stocks on forest land in the United States. - Science of the Total Environment 557-558: 469-478. 
Dracup E., KePPIE D. \& Forbes G. 2015. Woodland mouse and vole response to increased structural diversity following midrotation commercial thinning in spruce plantations. - Canadian Journal of Forest Research 45: 1121-1131.

GoŁos P. \& KALISZEwSKi A. 2015. Wybrane aspekty wykorzystania biomasy drzewnej do celów energetycznych. - Leśne Prace Badawcze 76(1): 78-87.

Gutowski J. M., Bobiec A., Pawlaczyk P. \& Zub K. 2004. Drugie życie drzewa. s. 245. WWF Polska, Warszawa - Hajnówka.

Hajek P., Seidel D. \& Leuschner C. 2015. Mechanical abrasion, and not competition for light, is the dominant canopy interaction in a temperate mixed forest. - Forest Ecology and Management 348: 108-116.

HÄMÄLÄINEN A., KouKI J. \& LÕHMUS P. 2015. Potential biodiversity impacts of forest biofuel harvest: Lichen assemblages on stumps and slash of Scots pine. - Canadian Journal of Forest Research 45(10): 1239-1247.

Hammer Ø., Harper D. A. T. \& Ryan P. D. 2001. PAST: Paleontological statistics software package for education and data analysis. - Palaeontologia Electronica 4(1): 1-9.

Harmon M. E., Franklin J. F., Swanson F. J., Sollins P., Gregory S. V., Lattin J. D., Anderson N. H., Cline S. P., Aumen N. G., Sedell J. R., Lienkaemper G. W., Cromack K. \& Cummins K. W. 1986. Ecology of coarse woody debris in temperate ecosystems. - Advances in Ecological Research 15: 133-302.

Herrero C., Monleon V. J., Gómez N. \& Bravo F. 2016. Distribution of dead wood volume and mass in mediterranean Fagus sylvatica L. forests in Northern Iberian Peninsula. Implications for field sampling inventory. - Forest Systems 25(3): 1-12.

Faliński J. B. \& PaWlaczyK P. 1993. Zarys ekologii. - W: W. BugaŁa (red.), Grab zwyczajny Carpinus betulus L. Nasze drzewa leśne, s. 157-263. Sorus, Poznań - Kórnik.

Jaworski T., Plewa R., Tarwacki G., Sućko K., Hilszczański J. \& Horák J. 2019. Ecologically similar saproxylic beetles depend on diversified deadwood resources: From habitat requirements to management implications. - Forest Ecology and Management 449: 117462.

Johansson V., Felton A. \& Ranius T. 2016. Long-term landscape scale effects of bioenergy extraction on dead wood-dependent species. - Forest Ecology and Management 371: 103-113.

Jonsson B. G., Ekström M., Esseen P.-A., Grafström A., StÅhl G. \& Westerlund B. 2016. Dead wood availability in managed Swedish forests - Policy outcomes and implications for biodiversity. - Forest Ecology and Management 376: 174-182.

JuUtilainen K., Halme P., Kotiranta H. \& MonkKonen M. 2011. Size matters in studies of dead wood and wood-inhabiting fungi. - Fungal Ecology 4: 342-349.

JuUtilainen K., Mönkkönen M., KotiRanta H. \& Halme P. 2014. The effects of forest management on wood-inhabiting fungi occupying dead wood of different diameter fractions. - Forest Ecology and Management 313: 283-291.

Kapusta P., Kurek P., Piechnik Ł., Szarek-Łukaszewska G., Zielonka T., Żywiec M. \& Holeksa J. 2020. Natural and human-related determinants of dead wood quantity and quality in a managed European lowland temperate forest. - Forest Ecology and Management 459: 117845.

Kirchenbaur T., Fartmann T., Bässler C., Löffler F., Müller J., Strätz C. \& Seibold S. 2017. Small-scale positive response of terrestrial gastropods to dead-wood addition is mediated by canopy openness. - Forest Ecology and Management 396: 85-90.

KLOCKOw P., D'Amato A. \& BRADFORD J. 2013. Impacts of post-harvest slash and live-tree retention on biomass and nutrient stocks in Populus tremuloides Michx.-dominated forests, northern Minnesota, USA. - Forest Ecology and Management 291: 278-288. 
KRUYS N. \& JonsSON B. 1999. Fine woody debris is important for species richness on logs in managed boreal spruce forests of northern Sweden. - Canadian Journal of Forest Research 29(8): 1295-1299.

Kunttu P., Junninen K., KulJu M. \& Kouki J. 2018. Major wood-decay fungal groups have distinct occurrence patterns on woody substrates. - Baltic Forestry 24(2): 164-180.

KÜFFER N. \& SENN-IRLET B. 2005. Diversity and ecology of wood-inhabiting aphyllophoroid basidiomycetes on fallen woody debris in various forest types in Switzerland. - Mycological Progress 4: 77-86.

Küffer N., Gillet F., Senn-Irlet B., Aragno M. \& Job D. 2008. Ecological determinants of fungal diversity on dead wood in European forests. - Fungal Diversity 30: 83-95.

Laiho R. \& Prescott C. E. 2004. Decay and nutrient dynamics of coarse woody debris in northern coniferous forests: a synthesis. - Canadian Journal of Forest Research 34(4): 763-778.

Lasota J., BŁońska E., Piaszczyk W. \& Wiecheć M. 2018. How the deadwood of different tree species in various stages of decomposition affected nutrient dynamics? - Journal of Soils and Sediments 18: 2759-2769.

LitTLefield C. \& KeETON W. 2012. Bioenergy harvesting impacts on ecologically important stand structure and habitat characteristics. - Ecological Applications 22(7): 1892-1909.

LÕHMUS A. \& KRAUT A. 2010. Stand structure of hemiboreal old-growth forests: Characteristic features, variation among site types, and a comparison with FSC-certified mature stands in Estonia. - Forest Ecology and Management 260: 155-165.

LõHmus A., Kraut A. \& Rosenvald R. 2013. Dead wood in clearcuts of semi-natural forests in Estonia: Site-type variation, degradation, and the influences of tree retention and slash harvest. - European Journal of Forest Research 132: 335-349.

Lutes D. C., Keane R. E. \& Caratti J. F. 2009. A surface fuel classification for estimating fire effects. - International Journal of Wildland Fire 18: 802-814.

MANNING J. \& EDGE W. 2008. Small mammal responses to fine woody debris and forest fuel reduction in southwest Oregon. - The Journal of Wildlife Management 72: 625-632.

MAŇÁK V. \& Jonsell M. 2017. Beetle diversity in two types of fine woody debris: lessons for bioenergy harvest. - Forestry 90: 82-87.

Martínez S., NaKasone K. K. \& Bettucci L. 2019. Diversity of wood-inhabiting Agaricomycotina on wood of different size classes in riparian forests of Uruguay. - Mycoscience 60: 156-164.

Merganičová K., Merganič J., Svoboda M., BaČE R. \& Šebeň V. 2012. Deadwood in forest ecosystems. - W: J. A. Blanco \& Y.-H. Lo (red.), Forest ecosystems - More than just trees, s. 81-108. InTech, Rijeka.

McCARthy B. C. \& Bailey R. R. 1994. Distribution and abundance of coarse woody debris in a managed forest landscape of the central Appalachians. - Canadian Journal of Forest Research 24: 1317-1329.

MorrisSEy R., JENKInS M. \& SAUNDERs M. 2014. Accumulation and connectivity of coarse woody debris in partial harvest and unmanaged relict forests. - PLoS ONE 9(11): e113323.

MÜLLER J. \& BÜTLER R. 2010. A review of habitat thresholds for dead wood: a baseline for management recommendations in European forests. - European Journal of Forest Research 129(6): 981-992.

Nordén B., Götmark F., Tönnberg M. \& Ryberg M. 2004a. Dead wood in semi-natural temperate broadleaved woodland: contribution of coarse and fine dead wood, attached dead wood and stumps. - Forest Ecology and Management 194: 235-248.

Nordén B., Ryberg M., Götmark F. \& Olausson B. 2004b. Relative importance of coarse and fine woody debris for the diversity of wood-inhabiting fungi in temperate broadleaf forests. - Biological Conservation 117: 1-10. 
Nordén J., Åström J., Josefsson T., Blumentrath S., Ovaskainen O., Sverdrup-Thygeson A. \& NorDÉN B. 2018. At which spatial and temporal scales can fungi indicate habitat connectivity? - Ecological Indicators 91: 138-148.

Paillet Y., Chevalier H., Lassauce A., Vallet P., Legout A. \& Gosselin M. 2013. Integrating fertilisation and liming costs into profitability estimates for fuel wood harvesting: a case study in beech forests of eastern France. - Biomass and Bioenergy 55: 190-197.

Palviainen M., Finé L., Kurka A. M., Mannerkoski H., Pirrainen S. \& Starr M. 2004. Decomposition and nutrient release from logging residues after clear-cutting of mixed boreal forest. - Plant and Soil 263: 53-67.

Polo J. A, Hallgren S. W. \& Leslie D. 2013. Effect of long-term understory prescribed burning on standing and down dead woody material in dry upland oak forests. - Forest Ecology and Management 291: $128-135$.

Ranius T., Hämäläinen A., Gustaf E., Olsson B., EklöF K., Stendahl J., SJögren J., Sténs A. \& FelTON A. 2018. The effects of logging residue extraction for energy on ecosystem services and biodiversity: a synthesis. - Journal of Environmental Management 209: 409-425.

Riffell S., Verschuyl J., Miller D. \& Wigley T. 2011. Biofuel harvests, coarse woody debris, and biodiversity - A meta-analysis. - Forest Ecology and Management 261: 878-887.

Romano A., Costa A., Salvidio S., Menegon M., Garollo E., Tabarelli de Fatis K., Miserocchi D., Matteucci G. \& PedRINI P. 2018. Forest management and conservation of an elusive amphibian in the Alps: Habitat selection by the Golden Alpine Salamander reveals the importance of fine woody debris. - Forest Ecology and Management 424: 338-344.

SAdowski J., Moskalik T., ZASTOCKI D. \& WrOnA T. 2012. Wybrane gospodarcze i przyrodnicze aspekty zagospodarowania pozostałości zrębowych. - Studia i Materiały Centrum Edukacji Przyrodniczo-Leśnej w Rogowie 14(32): 228-235.

Seibold S., Bässler C., Baldrian P., Reinhard L., Thorn S., Ulyshen M., Weiss I. \& Müller J. 2016. Dead-wood addition promotes non-saproxylic epigeal arthropods but effects are mediated by canopy openness. - Biological Conservation 204: 181-188.

SÖDERBERG U., WulfF S. \& STÅHL G. 2014. The choice of definition has a large effect on reported quantities of dead wood in boreal forest. - Scandinavian Journal of Forest Research 29(3): 252-258.

Stalling C., Keane R. \& RetzlafF M. 2017. Surface fuel changes after severe disturbances in northern Rocky Mountain ecosystems. - Forest Ecology and Management 400: 38-47.

Stokland J., Sittonen J. \& Jonsson B. 2012. Biodiversity in dead wood. Ecology, biodiversity and conservation. s. xiv + 494. Cambridge University Press, Cambridge.

Ter-Mikaelian M. T., Colombo S. J. \& Chen J. 2008. Amount of downed woody debris and its prediction using stand characteristics in boreal and mixedwood forests of Ontario, Canada. - Canadian Journal of Forest Research 38: 2189-2197.

Thiffault E., Bechard A., Pare D. \& Allen D. 2015. Recovery rate of harvest residues for bioenergy in boreal and temperate forests: A review. - WIREs Energy and Environment 4: 429-451.

Tomusiak R., Mostrąg A., Kędziora W., Wilczak A., Dominiecki A., Lecyk M. \& Wojtan R. 2014. Zasoby martwego drewna leżącego w drzewostanach sosny zwyczajnej i sosny czarnej na wydmach nadmorskich w rezerwacie „Mierzeja Sarbska”. - Studia i Materiały Centrum Edukacji Przyrodniczo-Leśnej w Rogowie 41(4): 73-85.

VAN WAGNER C. E. 1968. The line intersect method in forest fuel sampling. - Forest Science 14: 20-26.

Vavrova P., Penttila T. \& Laiho R. 2009. Decomposition of Scots pine fine woody debris in boreal conditions: Implications for estimating carbon pools and fluxes. - Forest Ecology and Management 257: 401-412. 
Vitkova L., BaČE R., Svoboda M. \& Kuucukov P. 2018. Deadwood management in Central European forests: Key considerations for practical implementation. - Forest Ecology and Management 429: 394-405.

Woodall C. W., Heath L. S. \& Smith J. E. 2008. National inventories of down and dead woody material forest carbon stocks in the United States: Challenges and opportunities. - Forest Ecology and Management 256: 221-228.

Woodall C. W., Walters B. F., Oswalt S. N., Domke G. M., Toney C. \& Gray A. N. 2013. Biomass and carbon attributes of downed woody materials in forests of the United States. - Forest Ecology and Management 305: 48-59.

Zhao W., Blauw L. G., van Logtestijn R. S. P., Cornwell W. K. \& Cornelissen J. H. C. 2014. Interactions between fine wood decomposition and flammability. - Forests 5: 827-846.

\section{SUMMARY}

Fine woody debris (FWD), that is, broken or fallen branches and twigs of trees and shrubs $<10 \mathrm{~cm}$ thick, is a category of deadwood whose role in forest ecosystems is rarely investigated. This role seems to be quite large in managed stands where coarse woody debris (CWD) is scarce. The aim of this study was to determine the amount of downed FWD in managed stands and nature reserves, to compare it with the amount of downed CWD, and to identify the factors affecting the FWD variability.

The study was performed in the Niepołomice Forest (Fig. 1), which is a large complex of lowland forests in southern Poland included on the list of Natura 2000 areas. FWD, CWD and selected tree stand parameters were measured in 99 study plots $(20 \times 100 \mathrm{~m}$ each) established in mixed stands (Pinus sylvestris-dominated; $\mathrm{N}=49$ ) and deciduous stands (with Carpinus betulus, Tilia cordata and Quercus robur; $\mathrm{N}=50$ ). FWD was estimated based on the line intersect method, and CWD and stand parameters were determined based on measurements of all individual trees and pieces of deadwood found within 0.4 ha.

The volume of downed FWD in managed stands ranged from 0.9 to $16.9 \mathrm{~m}^{3} \mathrm{ha}^{-1}$ (median: $5.0 \mathrm{~m}^{3} \mathrm{ha}^{-1}$ ). The median value for FWD was twice the volume of downed CWD (Fig. 2a). The share of FWD in the total volume of downed deadwood ranged from 7.7\% to $100 \%$ (median: 64.4\%) (Fig. 3). In the reserves the volume of downed deadwood was between 3.1 and $11.3 \mathrm{~m}^{3} \mathrm{ha}^{-1}$ (FWD) and between 13.2 and $175.4 \mathrm{~m}^{3}$ $\mathrm{ha}^{-1}$ (CWD). The average share of FWD was only $19.1 \%$. Most of the FWD belonged to the first class of thickness $(5-10 \mathrm{~mm})$. In subsequent classes the number of FWD pieces decreased sharply; almost $98 \%$ of FWD did not exceed $50 \mathrm{~mm}$ (Fig. 4). The type of forest significantly affected FWD; its volume was higher in deciduous than in mixed forests (Fig. 2b). Among other stand parameters, the number of tree species correlated most with FWD volume $\left(r_{s}=0.41, p<0.0001\right.$, Tab. 1$)$.

The study showed a significant shortage of downed CWD in the Niepołomice Forest, largely the result of forest management. The limited possibility of CWD accumulation in managed stands makes downed FWD the prevailing category of deadwood in the forest area. As such, it may be an important factor in maintaining assemblages of deadwood-dependent organisms.

Wptynęto: 07.02.2020 r.; przyjęto do druku: 05.03.2020 r. 